\title{
Idiopathic Intracranial Hypertension with Normal Cerebrospinal Fluid Pressure
}

\author{
Masoud Aghsaei Fard, MD, FICO \\ Department of Ophthalmology, Farabi Eye Hospital, Tehran University of Medical Sciences, Tehran, Iran \\ ORCID: \\ Masoud Aghsaei Fard: https://orcid.org/0000-0003-4005-2967
}

J Ophthalmic Vis Res 2019; 14 (4): 532-533

Sir,

I have read with enthusiasm the article published recently, ${ }^{[1]}$ based on which I would like to raise several concerns:

1. It is unclear how the diagnosis of idiopathic intracranial hypertension was made. In idiopathic intracranial hypertension, the opening pressure should be high. Based on this study, every patient with pale optic disc and normal lumbar puncture should be diagnosed as having idiopathic intracranial hypertension. The opening pressure of $18 \mathrm{~cm} \mathrm{H} 2 \mathrm{O}$ measured in this case report is not considered high. Additionally, the position (supine or lateral decubitus) during the lumbar puncture was not disclosed in the published article. In a large study conducted to find the reference range for cerebrospinal fluid pressure in 472 children, ${ }^{[2]}$ a threshold value of $28 \mathrm{~cm} \mathrm{H} 2 \mathrm{O}$ in the lateral recumbent position was set for high intracranial pressure. Authors recommended that for children an opening pressure above $28 \mathrm{~cm} \mathrm{H} 2 \mathrm{O}$ should be considered as elevated intracranial pressure. Another study also considered cerebrospinal fluid measures $\leq 28 \mathrm{~cm} \mathrm{H} 2 \mathrm{O}$ as "normal" for most children. ${ }^{[3]}$ The two case reports that the authors cited with normal cerebrospinal fluid pressure had other features of idiopathic intracranial hypertension such as papilledema, headache, and pulsatile tinnitus. ${ }^{[4]}$

2. The pale optic nerve thickness in this study was transformed confirming papilledema, which seems strange. In other words, the patient's retinal nerve fiber layer optical coherence tomography (RNFL OCT) values were $66 \mu \mathrm{m}$ (in Figure 3(B), 41 $\mu \mathrm{m})$ and $54 \mu \mathrm{m}$ in the text; based on the authors' previous study, these were transformed to 400 and $560 \mu \mathrm{m}$ thickness consistent with papilledema. No similar methods exist in the literature, except the authors' previous article in the Journal of Contemporary Medicine Science. ${ }^{[5]}$ If we accept this transformation in RNFL thickness, all optic atrophies with double hump appearance on RNFL OCT such as glaucoma and ischemic optic neuropathies would have papilledema.

3. Figure $1(C)$ had a very poor quality. The ganglion cell layer had artifacts and comparisons with Figures $3(\mathrm{~B})$ and $3(\mathrm{C})$ (posttreatment) are not reasonable and do not support their claim that GC atrophy has improved.

4. Authors stated that asymptomatic mitochondrial mutation for Leber's hereditary optic neuropathy (LHON) could be present in general population, however, the patient in question had signs of optic neuropathy (i.e., optic atrophy).

5. Spontaneous visual recovery is possible in LHON with 14,484 mutation, and therefore visual improvement in this patient could also be explained with the natural course of LHON.

\section{Financial Support and Sponsorship}

Nil.

\section{Conflicts of Interest}

There are no conflicts of interest.

\section{REFERENCES}

1. Sajjadi H, Poorsalman H. Previously diagnosed Leber's hereditary optic neuropathy with clinical signs of idiopathic intracranial hypertension responsive to acetazolamide therapy. J Ophthalmic Vis Res 2019;14:109-113. 
2. Avery RA, Shah SS, Licht DJ, Seiden JA, Huh JW, Boswinkel J, et al. Reference range for cerebrospinal fluid opening pressure in children. N Engl J Med 2010;363:891893.

3. Avery RA. Interpretation of lumbar puncture opening pressure measurements in children. $J$ Neuroophthalmol 2014;34:284-287.

This is an open access journal, and articles are distributed under the terms of the Creative Commons Attribution-NonCommercial-ShareAlike 4.0 License, which allows others to remix, tweak, and build upon the work non-commercially, as long as appropriate credit is given and the new creations are licensed under the identical terms.

\section{Correspondence to:}

Masoud Aghsaei Fard, MD, FICO. Farabi Eye Hospital, Tehran University of Medical Sciences, Tehran 13366, Iran. Email: masood219@gmail.com

Received: 06-02-2019

Accepted: 01-04-2019
4. Suh SY, Kim SJ. IIH with normal CSF pressures? Indian J Ophthalmol 2013;61:681-682.

5. SAJJADI F, MH Khoshnevisan, JF Doane, Sajjadi H. New predictive value of optical coherence tomography analysis in the diagnosis of idiopathic intracranial hypertension. Journal of Contemporary Medical Sciences 2017, [S.I.],3, (10), Date accessed: 08 oct. 2019.

\section{Access this article online}

Website:

https://knepublishing.com/index.php/JOVR

DOI:

10.18502/jovr.v14i4.5475

How to cite this article: Fard MA. Idiopathic Intracranial Hypertension with Normal CSF Pressure. J Ophthalmic Vis Res 2019;14:532-533. 